\title{
KEBINEKAAN BERAGAMA DALAM PERSPEKTIF HUKUM ISLAM DAN UNDANG- UNDANG DI INDONESIA
}

\author{
Ahmad Subekti \\ Fakultas Agama Islam Universitas Islam Malang \\ e-mail: ahmad.subekti@unisma.ac.id
}

\begin{abstract}
Abstrak
Indonesia masih dalam tahap menumbuhkan kebinekaan yang sesungguhnya setelah begitu lama berbeda-beda tetapi tetap satu, dalam kondisi Orde Baru yang represif. Persoalan terbesar saat ini adalah apakah kita masih memiliki benihbenih toleransi dalam keberagaman kita? Apakah keluarga demi keluarga, masingmasing umat beragama dan para pemimpin di aras lokal hingga tertinggi telah menerapkan toleransi beragama dalam keseharian ? di era milenial ini Indonesia membutuhkan ratusan juta benih unggulan toleransi dalam beragama guna menjadikan Indonesia sebagai rumah bersama yang nyaman untuk semua. Metode kajian dalam penulisan ini menggunakan metode kualitatif yaitu kajian atas gagasan konseptual. bertumpu pada ketersediaan sumber data di perpustakaan (Library Research). Kebinekaan beragama dalam perspektif Hukum Islam adalah merupakan Sunnatullah (hukum kodrat). Nilai-nilai kebinekaan merupakan warisan tradisi Nusantara yang menjadi pemersatu bangsa ini. Oleh karena itu menjaga kebinekaan, khususnya dalam beragama di Indonesia adalah suatu keniscayaan. Kesadaran umat dan bangsa akan kebinekaan beragama serta menghargai nilai-nilai kemanusiaan dan kemerdekaan baik yang tercantum dalam Undang-Undang Dasar 1945 maupun yang terdapat dalam tradisi dan budaya bangsa Indonesia, akan menciptakan sikap toleransi dan kerukunan umat beragama di Indonesia semakin kokoh.
\end{abstract}

Kata Kunci: Kebinekaan, Agama, Hukum, Islam, dan Undang-Undang di Indonesia

\begin{abstract}
Indonesia is still in the stage of cultivating true diversity after so long being different but still one, in the repressive conditions of the New Order. The biggest problem now is do we still have the seeds of tolerance in our diversity? Does family
\end{abstract}

This work is licensed under Creative Commons Attribution Non Commercial 4.0 International License Available online on: http://riset.unisma.ac.id/index.php/fai/index 
for family, each religious community and leaders at the local level up to the highest have implemented religious tolerance in their daily lives? in this millennial era, Indonesia needs hundreds of millions of seeds of superior tolerance in religion in order to make Indonesia a comfortable shared house for all. The method of study in this paper uses qualitative methods, namely the study of conceptual ideas. relies on the availability of data sources in the library (Library Research). Religious diversity in the perspective of Islamic law is Sunnatullah (natural law). The diversity values are a legacy of the Archipelago's tradition of unifying this nation. Therefore maintaining diversity, especially in religion in Indonesia is a necessity. Awareness of the people and the nation for religious diversity and respect for the values of humanity and independence both contained in the 1945 Constitution and contained in the traditions and culture of the Indonesian nation, will create an attitude of tolerance and harmony among religious communities in Indonesia.

Keywords: Diversity, Religion, Law, Islam, and Law in Indonesia

\section{A. Pendahuluan}

Menteri Agama Lukman Hakim Saifuddin dalam Rapat Kerja Nasional Majelis Ulama Indonesia (Rakernas MUI) di Jakarta pada tanggal 23 November 2016 mengatakan bahwa masyarakat Indonesia sangat religius. Meski umat Islam menjadi mayoritas, antara agama dan negara tidak lantas dipisahkan, "Agama menjadi roh dalam bernegara". Beliau menuturkan, ada simbiosis mutualisme antara agama dan negara di Indonesia. Islam menjadi jiwa dalam semua aturan berbangsa dan bernegara. Dalam hubungan simbiosis mutualisme itu, negara perlu di kontrol, diimbangi, dan diawasi oleh agama. Sebab, negara bisa menyimpang dan menyalahgunakan kekuasaan, oleh karena itu "Agamawan bisa memberikan saran kepada negara", jelasnya.

Gejala menguatnya isu agama dan etnisitas dalam berbangsa dan bernegara merupakan tantangan tersendiri bagi bangsa indonesia. Sebagai contoh kasus penistaan agama menjadi isu nasional saat ini. Indonesia sebagai negara hukum (rechstaat) sekaligus sebagai negara beragama, berbeda dengan negara-negara di dunia Barat. Oleh karena itu, setiap kasus yang berpotensi penistaan / penodaan agama (defamation of religion) harus diproses secara hukum, sebab ada hukum yang mengatur penistaan agama.

Masyarakat muslim Indonesia mayoritas memiliki tingkat toleransi yang sangat tinggi. Oleh karena itu Indonesia seharusnya bisa menjadi negara

JAS: Volume 1 Nomor 2, 2019 
demokrasi modern. Artinya demokrasi yang bisa berjalan seiring dengan hukum Islam.

Agama dan kepercayaan yang tercantum dalam Undang-Undang Dasar 1945 memang masih sering diperdebatkan, baik dari kalangan ahli hukum, ahli bahasa, maupun ahli agama itu sendiri. Secara teoritis, kepercayaan adalah bagian dari agama. Sedangkan agama adalah suatu sistem kepercayaan (aqidah) yang dijalankan ajarannya (syariah) dengan sikap dan perilaku (akhlak) yang baik bagi pemeluknya.

Oleh karena itu, meski tetap menjadi bahan perdebatan hingga kini, secara eksplisit Undang-Undang Dasar 1945 mengakui keberadaan penghayat kepercayaan kepada Tuhan Yang Maha Esa di luar 6 (enam) agama yang diakui negara, yaitu agama Islam, Kristen, Katolik, Hindu, Buddha, dan Konghucu.

\section{B. Metode}

Metode kajian dalam penulisan ini menggunakan metode kualitatif. Metode ini bersifat lebih ke arah metode kajian atas gagasan konseptual. Sedangkan datadata yang dikumpulkan dan yang akan dianalisis bertumpu pada ketersediaan sumber data di perpustakaan (Library Research). Teknik analisis data yang digunakan dalam kajian ini adalah teknik analisis isi (Content Analysis) yakni sebuah teknik yang secara komprehensif berusaha menggali beragam keterangan dari pesan atau informasi yang disajikan dalam wujud lambang atau simbol tertentu yang terdokumentasikan. Sedang gambar data penelitian ini diperoleh dari beragam sumber yang bersifat kekinian dengan tidak meninggalkan refereni klasik.

\section{Hasil dan Pembahasan}

\section{Agama dalam Undang-Undang Dasar 1945 dan Perspektif Hukum Islam}

Dalam Undang-Undang Dasar 1945 Pasal 29 ayat (1) dan (2) dinyatakan : "Negara berdasar atas Ketuhanan Yang Maha Esa : Negara menjamin kemerdekaan tiap-tiap penduduk untuk memeluk agamanya masing-masing dan untuk beribadat menurut agamanya dan kepercayaan itu."

Dalam konteks kebinekaan beragama di Indonesia, terutama yang menyangkut tentang pemahaman Ketuhanan Yang Maha Esa pada Sila Pertama dalam Pancasila, menurut agama Islam sudah jelas bahwa Allah SWT, adalah satu. Dia adalah satu-satunya Tuhan.

Dalam perspektif Hukum Islam, konsep Ketuhanan Yang Maha Esa tidak lain adalah apa yang disebut dengan "Tauhid", demikian antara lain bunyi keputusan muktamar Nahdlatul Ulama Ke 26 di Situbondo Jawa Timur pada tahun 1984. 
Tafsir ini tidak dimaksud untuk menafikan hak hidup agama-agama lain, yang dianut di Indonesia. Karena "Tauhid" itulah keyakinan yang terdalam dan yang paling awal primordial) dari semua agama-agama yang ada di dunia. Al-Qur'an menyatakan sebagai berikut : "tidak pernah kami utus seorang rasul sebelum kamu (Muhammad) kecuali kepadanya. Kami ajarkan bahwa sesungguhnya tidak ada Tuhan kecuali Aku, maka sembahlah Aku" (QS. Al - Anbiya' [21] : 25).

Meskipun kita tahu masing-masing agama menganut syarat (cara keberagaman) yang berbeda-beda :

"Bagi masing-masing umat ada cara ibadah (kurban)nya sendiri untuk menyebut nama Allah atas rejeki yang dianugerahkanNya berupa hewan-hewan ternak: karena Tuhan kalian itu satu, maka kepadaNyalah kalian semua berserah diri, dan berilah kabar gembira kepada orang-orang yang tunduk-patuh" (QS. Al Hajj [22] : 34).

Dan masing-masing agama juga memiliki tempat ibadah yang berbeda-beda : "Dan sekiranya tidak ada pembelaan Allah atas keganasan manusia terhadap manusia yang lain, niscaya telah dihancurkan biara-biara Nasrani, gereja-gereja, sinagog-sinagog yahudi dan masjid-masjid yang didalamnya banyak disebut nama Allah...." (QS. Al Hajj [22] : 40).

Artinya, semua agama pada dasarnya, dan pada mulanya, mengajarkan keesaan Tuhan (tauhid). Perbedaannya, jika disebut demikian, adalah dalam tingkat ketegasan dan kelugasan bahasanya. Bersama dengan prinsip-prinsip yang lain, konsep Ketuhanan Yang Maha Esa ini membentuk satu kesatuan dasar Negara Republik Indonesia yang dikenal dengan Pancasila, yang secara harfiah berarti Lima Dasar, atau meminjam istilah Fiqih Islam, Al-Kulliyat Al Khams bagi Negara dan bangsa Indonesia yakni : "Ketuhanan Yang Maha Esa" sebagai landasan spiritualnya ; "Kemanusiaan Yang Adil dan Beradab" sebagai landasan moral dan etiknya; "Persatuan Indonesia" sebagai landasan sosialnya ; "kerakyatan Yang Dipimpin oleh Hikmah Kebijaksanaan dalam Permusyawaratan Perwakilan" sebagai acuan politiknya dan "Keadilan Sosial bagi seluruh Rakyat Indonesia" sebagai tujuan bersama dalam bernegara Mas'udi dalam (Sahal\&Aziz, 2015: 32).

Pasal diatas (pasal 29 UUD 1945) sangatlah jelas bahwa semua agama dihadapan Negara diperlakukan sama. Demikian itu bukan dalam pengertian bahwa secara substantive-teologis Negara menghakimi agama-agama yang dianut oleh warganya sebagai benar / haq semuanya. Juga bukan sebaliknya, bahwa semua agama yang dianut oleh warganya sebagai kebatilan dan kepalsuan.

Penghakiman seperti ini jelas bukan wewenang Negara. Pasal ini berlaku dalam pengertian bahwa agama-agama yang telah dianut oleh umat masing- 
masing sebagai warga Negara harus disikapi dan diperlakukan sama. Jika yang satu dibantu atau tidak dibantu, maka yang lain pun begitu. Jangan karena pejabatpejabatnya menganut agama tertentu maka penganut agama atau keyakinan yang lain didiskriminasi.

Norma ini sebenarnya universal, bukan hanya untuk kelompok agama tapi juga yang lainnya, termasuk partai atau kesukuan. Penegasan Al Qur'an tentang perlakuan yang adil tanpa diskriminatif harus benar-benar diacu. Sebagaimana firman Allah SWT :

"Wahai orang-orang yang beriman, jadilah kalian orang-orang yang selalu menegakkan (kebenaran) karena Allah menjadi saksi dengan adil ; dan janganlah sekali-kali kebencian kalian terhadap suatu kaum mendorong kalian berlaku tidak adil. Bertindak adillah, karena adil itu lebih dekat kepada taqwa : dan bertaqwalah kepada Allah, sunggh Allah Maha mengetahui apa yang kalian perbuat" (QS. Al Maidah [5] : 8)

Juga dengan semangat keadilan, Negara berkewajiban menjamin tidak adanya aksi penistaan atas agama atau keyakinan oleh penganut agama lain. Biarlah semua orang meyakini agamanya sebagai yang paling benar, bahkan satusatunya yang benar, tanpa harus menistakan agama dan atau keyakinan orang lain sebagai suatu kepalsuan atau kesesatan. Normanya sama : Jika anda tidak suka agama anda dihina, maka janganlah anda menghina agama saudara anda. Sebaliknya, jika anda suka orang menghormati agama anda, maka hormatilah agama saudara anda. Al Qur'an mengajarkan sebagaimana bunyi firman Allah SWT : "Dan janganlah kalian mencaci sesembahan yang mereka sembah selain Allah, karena mereka nanti akan memaki Allah dengan melampaui batas tanpa pengetahuan" (QS. Al-An'am [6] : 108).

Perihal kebenaran yang diyakini oleh masing-masing umat beragama. Negara juga tidak berhak campur tangan. Apa yang secara eksklusif benar menurut Islam dan harus dipatuhi oleh umatnya biarlah menjadi urusan umat Islam sendiri, juga apa yang secara eksklusif benar menurut Kristen dan harus diamalkan oleh umatnya biarlah menjadi urusan umat Kristen sendiri, dan seterusnya. Misalnya bagaimana masing-masing agama mendefinisikan dan memanggil Tuhannya, apakah dengan sebutan Allah, atau Sang Yang Widiwasa, atau lainnya; atau bagaimana memuja kebesaranNya dalam ibadah shalat di Masjid atau Kebaktian di Gereja atau mengatur disiplin internal umatnya; biarlah semua itu menjadi urusan rumah tangga masing-masing komunitas penganutnya.

Tidak pada tempatnya Negara harus terlibat atau dilibatkan melalui kebijakan (UU atau Perda) berikut aparat represifnya, misalnya, untuk memaksa- 
maksa orang Kristen untuk pergi ke gereja setiap hari Minggu, atau memaksa orang Hindu ke Pura, orang Budha ke Wihara, dan orang Konghucu ke Kelenteng.

Negara sebagai lembaga publik yang bersifat inklusif hanya berkewajiban melindungi hak dan kepentingan segenap warganya, termasuk hak meyakini dan mengamalkan ajaran agamanya, tanpa membeda-bedakan antara penganut agama yang satu dan penganut agama yang lain. Jika ternyata penganut agama tertentu kurang setia menjalankan agamanya, maka itu menjadi urusan pribadi yang bersangkutan, atau paling jauh urusan komunitas agamanya, maka itu menjadi urusan pribadi yang bersangkutan, atau paling jauh urusan komunitas agamanya dan pemimpinnya. Jika sang pemimpin berhasil mendorong penghayatan dan pemahaman yang kuat pada jemaahnya, tentunya semua akan menunaikan perintah agamanya dengan baik. Jika gagal, dan umat kurang taat pada agamanya, kegagal itu jangan dilimpahkan kepada Negara yang sejatinya memang tidak bertanggung jawab untuk itu.

Apa yang sudah ditegaskan di atas perihal kebebasan setiap warga Negara untuk memeluk dan mengamalkan agamanya juga berlaku terhadap keyakinannya. Yang dimaksud dengan agama dalam pasal 29 UUD 1945 adalah keyakinan induk : Islam, Katolik, Kristen, Hindu, Budha, Konghucu, dan sebagainya. Sedang yang dimaksud dengan "Keyakinan" adalah apa yang dalam Islam disebut dengan aliran, mazhab, atau sekte dalam Kristen. Maka tersebutlah dalam Islam, misalnya Sunni, Syiah, Khawarij, dan sebagainya. Didalam Sunni tersebut terdapat penganut mazhab Syafi'i, Hanafi, Maliki, dan Hambali. Dalam Kristen terdapat sekte Katolik, Protestan, Ortodok, Mormon, dan sebagainya. Dalam Prostestan ada Presbitarian, Lutheran, Metodis, dan sebagainya. Juga dalam Hindu, Budha, dan Konghucu, masing-masing memiliki sistem keyakinan yang berbeda. Singkatnya, disemua agama selalu terdapat alur keyakinan yang tidak tunggal. Maka posisi Negara terhadap perbedaan keyakinan (mazhab, sekte, aliran, denominasi) juga harus sama : adil, proporsional, tidak diskriminatif, dan mengayomi semuanya.

Seperti diketahui, ekspresi paling primer dari perbedaan keyakinan ini hadir dalam tata cara peribadatan atau doa dan pernak-perniknya. Dalam agama umat Kristiani, misalnya, dalam tradisi Katolik ibadah dimulai dengan salam dan mengenal sakramen pengakuan dosa, sementara dalam ajaran Protestan tidak ada. Sebaliknya, di lingkungan Protestan sendiri ada perbedaan satu denominasi dengan denominasi yang lain, meskipun hanya kecil saja. Atau dalam Islam, penganut mazhab Syafi'i dalam Shalat Subuh penganut doa qunut, sementara pengikut mazhab Hambali tidak. Juga dalam tradisi agama Hindu, Budha, dan

JAS: Volume 1 Nomor 2, 2019 
Konghucu, masing-masing sekte atau keyakinan memiliki tradisi peribadatan yang tidak sepenuhnya sama dengan yang lain.

Inilah mengapa dalam teks keonstitusi kita pasal 29 ayat (2) UUD 1945 menegaskan : Negara vmenjamin kemerdekaan tiap-tiap penduduk untuk memeluk agamanya masing-masing dan beribadah menurut agama dan kepercayaan (baca : mazhab/aliran)-nya itu. Artinya, apabila perbedaan mazhab atau aliran dalam satu agama yang sama dan tidak bersifat mendasar, tentunya lebih dijamin dan dihormati. Inilah keadaban dan kearifan dalam beragama yang didorong oleh kalimat terakhir pasal 29 ayat (2) UUD 1945 tersebut.

Oleh sebab itu, jika negara harus berperan dalm kehidupan agama dan umatnya, maka hal itu berkisar pada dua hal : pertama, peran preventif dalam hal menjaga agar relasi antar umat penganut agama/keyakinan yang berbeda tetap dalam harmoni, tidak terjerumus dalam konflik horizontal antar-umat yang dapat meruntuhkan persatuan bangsa dan keutuhan negara. Kedua, peran promotif untuk mengimplementasikan dan memajukan nilai-nilai luhur universal yang diunggulkan oleh agama-agama panutan masing-masing. Sebutlah, nilai kasih dan pemihakan kepada yang lemah dari Kristianitas ; nilai keadilan untuk semua terutama yang terpinggirkan dari Islam, nilai kesederhanaan dan anti kerakusan dari Budhis, anti kekerasan (nonviolence) dan peduli lingkungan dari Hinduisme, serta peduli kemanusiaan dan selalu nilai-nilai perenial tersebut negara wajib menjiwainya dan mengimplementasikannya dengan penuh kesungguhan dan keikhlasan.

Justru dengan mengaktualisasikan nilai-nilai universal itulah maka, dalam perspektif spiritual duniawi mendapatkan makna spiritualnya, diperkokoh keberadaannya dan layak dibela oleh semua umat beragama. Tanpa misi suci (mission sacred) seperti itu negara hanya akan menjadi alat nafsu kekuasaan dan keserakahan para elitnya belaka apapun ideologinya (Sahal\&Aziz, 2015: 320) .

\section{Ketuhanan Yang Maha Esa menurut Lintas Agama \\ a. Islam}

Menurut Islam, Ketuhanan Yang Maha Esa dalam Al-Qur'an sudah jelas, yaitu bahwa Allah SWT adalah satu. Dia adalah satu- satunya Tuhan : "Tidak ada Tuhan selain Allah" (Qs. Muhammad [47] : 19) ; "Katakanlah (Muhammad) Dialah Allah Yang Maha Esa, Allah tempat meminta segala sesuatu, (Allah) tidak beranak dan tidak pula diperanakkan, dan tidak ada sesuatu yang setara dengan Dia" (Qs. Al Ikhlas \{112\} : 1-4); Dia adalah "Pencipta segala sesuatu” (Qs. Al An'am [6] : 102), sebelum memulai ciptaan Allah sendirian; kekekalan hanyalah milik Allah : "Dialah yang awal dan akhir"(Qs. Al- Hadid [57] : 3), sebagai penguasa tertinggi alam 
semesta : "Allah berkuasa untuk melakukan segala sesuatu" (Qs.Al-Maidah [5] : 17), dan "Allah melakukan apa yang Dia Kehendaki" (Qs. Al-Baqarah [2] : 253) Allah itu unik dan tidak menyerupai apapun : "Tidak ada sesuatu yang menyerupai-Nya" (Qs. Al-Syura [42] : 11).

Allah itu halus dan tidak terjangkau oleh indera siapapun : "Dia tidak dapat dicapai oleh penglihatan mata, sedang Dia dapat melihat segala yang kelihatan; dan Dialah Yang Maha Halus lagi Maha Mengetahui" (QS.Al - An'am [6] : 103). Segala sesuatu dan setiap orang tunduk kepadanya, secara sukarela ataupun terpaksa : "Kepada-Nyalah menyerahkan diri segala suka maupun terpaksa" (Qs. Al-Imron [3] : 83 ).

Al-Qur'an menganggap setiap Tuhan selain Allah sebagai kepalsuan. AlQur'an mengutuk keras politisme, yakni penyekutuan Tuhan-Tuhan dengan Allah. Al-Qur'an menyatakan lebih dari satu kali bahwa menyekutukan Allah merupakan dosa terbesar dan satu-satunya dosa yang tidak bisa diampuni. "sesungguhnya Allah merupakan tidak akan mengampuni dosa syirik, dan Dia mengampuni segala dosa yang selain dari (Syirik) itu, bagi siapa yang dikehendaki-Nya. Barang siapa mempersekutukan Allah, maka sungguh Dia telah berbuat dosa yang besar " (QS.Al Nisa' [4] : 48).

Satu perbedaan penting antara gambaran tentang Allah di dalam Al-Qur'an dan Perjanjian Baru, setidaknya menurut pemahaman yang paling popular, adalah bahwa Allah dalam Al-Qur'an itu "Satu", sedangkan Allah dalam Perjanjian Baru itu adalah sebuah "kesatuan".

Menurut Al-Qur'an, Ketuhanan Allah tidak bisa dibagi atau dibelah. Segala sesuatu dan siapapun selain Allah hanyalah ciptaan dan hamba-Nya. Lebih dekat dengan Allah, tetapi tidak membuatnya dekat dengan Ketuhanan. Itu justru menegaskan kahambaannya. Menjadi lebih dekat dengan Allah berarti menjadi lebih dekat dengan kesempurnaan sebagai muslim, dan yang terakhir ini adalah seseorang yang telah meraih ketundukan dan penyerahan diri total kepada Allah. Inilah keadaa dimana individu itu tidak lagi menjadi hamba lantaran dorongan sesaat saja, melainkan juga dengan kehendak.

Allah sebagai "Al-Rabb", dalam memelihara dan mengembangkan atau, mengatur makhluk-makhluk-Nya mempunyai lima (5) ciri dasar, yaitu sebagai berikut :

1) Allah menganugrahkan kepada makhluk-makhlukNya segala kebaikan tanpa mengharap balasan dari mereka. Apapun yang diperintahkan oleh Allah kepada manusia demi keuntungan manusia sendiri. Jika manusia mengikuti

JAS: Volume 1 Nomor 2, 2019 
jalan yang telah ditunjukkan Allah, dia akan beruntung; jika tidak, berarti manusia telah menganiaya dirinya sendiri.

2) Allah menganugerahkan kepada makhluk-makhlukNya segala sesuatu demi kelangsungan hidup dan kesejahteraan mereka.

3) Allah telah mengetahui lebih dulu apa-apa yang dibutuhkan oleh makhlukmakhlukNya dan menyediakan kebutuhan-kebutuhan tersebut sebelum mereka merasakan arti pentingnya.

4) Pemberian Allah bersifat universal. Allah tidak mendiskriminasikan antara yang baik dan yang buruk, yang berbudi dan yang jahat, yang beriman dan yang kafir. Semuanya akan diberi karunia di dunia oleh Allah. Keempat ciri Allah dalam memelihara alam tersebut diatas merupakan cerminan sifat $A l$ Rahman Allah (Allah Yang Maha Pengasih).

5) Allah sebagai Dzat Yang Maha Penyayang (al-Rahim). Allah melaksanakan keadilan berdasarkan kasih sayang. Mereka yang taat kepada Allah akan mendapatkan karunia atau pahala di dunia dan akhirat, sedangkan mereka yang ingkar kepada Allah akan mendapatkan siksaan di dunia dan akhirat (Sardar, 1989: 47).

\section{b. Kristen - Katolik}

Menurut agama Kristen - Katolik, Ketuhanan Yang Maha Esa adalah Allah Tritunggal. Dari Allah Tritunggal kita dapat belajar tentang hubungan antara Tritunaggal (Trinitas), Ketuhanan, dan umat manusia. Dari Allah Tritunggal, kita dapat belajar tentang kepedulian dan kasih Allah.

Kasih Allah Tritunggal yang memberikan keselamatan bagi hidup orangorang Kristen-Katolik. Hal ini dapat dijadikan sebagai fondasi menyatakan kepedulian manusia melalui pelayanan rohani dalam pengajaran. Dalam karya keselamatan yang diberikan Allah Tritunggal, kita dapat belajar tentang keselamatan kita dari desa dan berbagai bentuk penindasan yang membuat kita kehilangan nilai.

Tertullian, yang memperkenalkan istilah "trinitas" dari bahasa latin, mengajarkan konsep satu Allah dalam tiga sosok : Sang Bapa, Sang Anak, dan Roh Kudus. Ketiganya berbeda, tetapi tidak terpisah. Karena ketiga sosok ini tidak terpisah atau terbelah, Allah itu satu, bukan tiga. Trinitas Tertullian karenannya merupakan sebentuk monoteisme bukan triteisme (Fathoohi, 2013:423).

Dalam versi lain, menyatakan bahwa Allah itu satu didalam tiga aspek, sang Bapa, sang Anak, dan Roh Kudus bukanlah sosok-sosok terpisah, melainkan manifestasi berbeda dari Allah. Dengan demikian, yang menderita di tiang salib 
adalah Allah, karenannya pandangan ini juga disebut "patripassionism", yang diturunkan dari kata-kata bahasa latin untuk "bapa" dan "menderita".

Pada tahun 325 masehi, Kaisar Konstantin mengadakan dan mengawal Konsili Ekumenikal pertama, yang dilangsungkan di Nicea. Para uskup yang ikut serta, yang jumlahnya menurut beberapa sumber berbeda antara 250 dan 318, mengeluarkan dekrit pertama yang menyatakan tentang status sang Bapa dan sang Anak, serta hubungan mereka pada Roh Kudus. Susunan kata dekrit tersebut berbunyi sebagai berikut :

“Kami percaya pada Satu Allah, Sang Bapa Yang Maha Kuasa, pencipta segala sesuatu yang tampak dan tak tampak; Dan pada satu Tuhan Yesus Kristus, Anak Allah, dilahirkan dari Sang Bapa, satu-satunya yang dilukiskan dari zat sang Bapa, Allah dari Allah, cahaya dari cahaya, Allah yang benar dari Allah yang benar, dilahirkan bukan dibuat, dari satu substansi bersama sang Bapa, yang melaluinya segala sesuatu mengada, semua yang dilangit dan semua yang dibumi, yang demi kita manusia, dan demi keselamatan kita turun dan mendaging menjadi manusia, menderita dan bangkit kembali pada hari ketiga, naik ke langit akan datang untuk mengadili yang hidup dan yang mati. Dan pada Roh Kudus".

Dalam setengah abad berikutnya, yaitu tepatnya pada tahun 381 masehi, 150 uskup menyelenggarakan Konsili Ekumenikal kedua di Konstantinopel, kemudian muncullah doktrin Trinitas yang berbunyi:

"Kami percayapada satu Allah, sang Bapa, Yang Maha Kuasa, pencipta langit dan bumi, segala sesuatu yang tampak dan tak tampak; Dan p[ada satu Tuhan Yesus Kristus, satu-satunya Anak Allah yang dilahirkan, dilahirkan dari Bapa sebelum seluruh zaman, cahaya dari cahaya, Allah yang benar dari Allah yang benar, dilahirkan bukan dibuat, dari satu substansi bersama Sang Bapa, yang melaluinya segala sesuatu mengada, yang demi kita manusia dan demi keselamatan, kita dating turun dari sorga, dan mendaging dari sorga, dan mendaging dari Roh Kudus dan Perawan Maria dan menjadi manusia, dan disalibkan demi kita dibawah perintah Pontius Pilatus, dan menderita dan dikuburkan, dan bangkit kembali pada hari ketiga menurut Kitab Suci dan naik ke langit. Dan duduk di sebelah kanan Sang Bapa, dan akan dating kembali dengan keagungan untuk mengadili yang hidup dan yang mati, pemilik kerajaan yang tak akan berakhir; Dan pada Roh Kudus, Tuhan dan Pemberi kehidupan, yang berasal dari Sang Bapa, yang dengan Sang Bapa dan Sang Anak bersama-sama disembah dan diagungkan bersama-sama, yang berbicara melalui nabi-nabi; di dalam satu Katolik dan Gereja apostolic suci. Kami mengakui satu pembaptisan untuk menghapuskan dosa-dosa; kami menantikan kebangkitan

JAS: Volume 1 Nomor 2, 2019 
kembali orang mati dan kehidupan dunia yangakan datang”. Amin (Kelly\&Creeds, 1999: 298).

\section{c. Hindu}

Dalam agama Hindu, Tuhan merupakan sumber utama segala sesuatu, dan kesadaran rohaniNya mengalir ke setiap makhluk hidup. Tuhan - Sri Krishna sebagai Personalitas Tuhan Yang Maha Esa telah bersabda dalam Bhagavadgita (15 :15) :

"sarvasya edham hrdi sannivisto mattah smstir jnanam apohanaim ca vedais ca sarvair aham eva vedyo Vedanta - krd - veda - vid - eva caham"

Artinya : "Aku bersemayam dalam hati setiap orang, ingatan, pengetahuan, dan kelupaan berasal dari Ku. Dari seluruh veda aku yang harus diketahui. Sesungguhnya, Aku lah penyusun Vedanta, dan Akulah yang mengetahui Veda (Singh, 2009:38).

Ketuhanan Yang Maha Esa dalam agama Hindu disebut Ida Sang Hyang Widhi Wasa yang dikaitkan dengan konsep Brahman, yang artinya "Dia yang tak terpikirkan, Dia yang tak dapat dipahami, atau Dia yang tak dapat dibayangkan".

"Hyang" merupakan sebutan untuk keberadaan spiritual yang memiliki kekuatan supranatural bagaikan matahari di dalam mimpi. Kedatangannya dalam hidup seseorang memberikan kesenangan tanpa jeda dalam waktu lama yang tak dapat dibedakan antara mimpi dan realita. Orang-orang Indonesia umumnya mengenal kata ini sebagai penyebutan untuk penyebab keindahan, penyebab semua ini ada (pencipta), penyebab dari semua yang dapat disaksikan atau secara sederhana disebut Tuhan.

"Widhi" artinya pengetahuan memiliki makna penghapus ketidaktahuan. Widhi dapat berupa : cahaya, suara, wujud tersentuh, sensasi tersensori, memori pikiran, rasa emosional, radiasi bintang, pengertian tanda, rasa kecakapan dan lain-lain, Widhi ini sangat terkait dengan dharma, atau lingkungan yang merupakan pustaka abadi dimana manusia dapat membaca keseluruhan pengetahuan tentang widhi. Sedangkan "Wasa" artinya Tuhan.

Sifat-sifat Tuhan dalam agama Hindu dilukiskan sebagai yang mutlak, yang berarti besar tak terbatas. Dia adalah karakter batasan itu sendiri. Namun, Dia juga bersifat immanent pada segala yang tercipta. Dia adalah impersonal, perwujudan Tuhan yang berada dimana-mana. Dia Yang Maha Mengetahui dan Maha Kuasa. Dia merupakan perwujudan keadilan kasih saying, dan keindahan. Dalam kenyataannya, Dia merupakan perwujudan dari segala kualitas terberkati yang senantiasa dapat dipahami manusia. Dia senantiasa siap mencurahkan anugerah, kasih, dan berkahNya pada setiap ciptaanNya. 
Dengan kata lain, tujuan utama penciptaan dunia semesta ini adalah untuk mencurahkan berkahNya pada makhluk-makhluk, membimbingnya secara bertahap dari keadaan yang kurang sempurna menuju keadaan yang lebih sempurna. Dengan mudah Dia disenangkan dengan doa dan permohonan dari para pemujaNya. Namun tanggapanNya pada doa ini dituntut oleh prinsip yang hendaknya tidak bertentangan dengan hukum kosmis yang berkenaan dengan kesejahteraan umum dunia dan hukum karma yang berkaitan dengan kesejahteraan pribadi-pribadi khususnya.

Konsep Tuhan dalam agama Hindu memiliki dua gambaran khas, yaitu tergantung pada kebutuhan dan selera pemujaNya. Dia dapat dilihat dalam suatu wujud yang mereka sukai untuk pemujaan dan menanggapinya melalui wujud tersebut. Dia juga dapat menjelmakan diriNya diantara makhluk manusia untuk membimbingnya menuju kerajaan KedewataanNya. Dan penjelmaan ini merupakan suatu proses berlanjut yang mengambil tempat dimana pun dan kapan pun yang dianggapNya perlu.

\section{d. Buddha}

Ketuhanan Yang Maha Esa menurut agama Buddha, sebagaimana yang tertera dalam kitab suci Sutta Pitaka (udana VIII : 3), yaitu :

"Ketuhanan Yang Maha Esa adalah suatu yang tanpa aku (anatta), yang tidak dapat dipersonifikasikan dan tidak dapat digambarkan dalam bentuk apapun. Tetapi dengan adanya yang mutlak yang tidak berkondisi (asamkhata) maka manusia yang berkondisi (samkhata) dapat mencapai kebebasan dari lingkaran kehidupan (samsara) denmgan cara bermeditasi. Ketahuilah para bhikkhu bahwa ada sesuatu yang tidak dilahirkan. Yang tidak menjelma, yang tidak tercipta, yang mutlak duhai para bhikkhu, apabila tidak ada yang tidak dilahirkan, yang tidak menjelma, yang tidak ciptakan, yang mutlak, maka tidak akan mungkin kita dapat bebas dari kelahiran, penjelmaan, pembentukan, pemunculan dari sebab yang lalu. Tetapi para bhikkhu, menjelma, yang tidak tercipta, yang mutlak, maka ada kemungkinan untuk bebas dari kelahiran, penjelmaan, pembentukan, pemunculan dari sebab yang lalu.

Ungkapan di atas merupakan konsep Ketuhanan Yang Maha Esa dalam agama Buddha Sanghyang Adi Buddha adalah istilah yang disepakati dan dipergunakan oleh Sangha Agung Indonesia dan Majelis Buddhayana Indonesia sebagai sebutan Tuhan Yang Maha Esa.

Adi - Buddha merupakan Buddha primordial Yang Esa, atau dinamakan juga Paramadi Buddha (Buddha Yang Pertama dan Tiada Terbandingkan).

JAS: Volume 1 Nomor 2, 2019 
Dalam aliran Mahayana, Buddha memiliki tiga tubuh (Trikaya), yaitu : "Tubuh Perubahan" (Nirmanakaya) untuk mengajar manusia biasa; "Tubuh Kenikmatan" (Sambhogakaya) yaitu tubuh cahaya atau perwujudan surgawi; dan "Tubuh Dharma" (Dharmakaya) yang kekal, ada dimana-mana, bukan realitas perseorangan, esa, bebas dari pasangan yang berlawanan, ada dengan sendirinya (svabhavakaya).

Dalam Kitab Suci Sang Hyang Kamahayanikan pupuhke 19 dijelaskan bahwa Sang Buddha Gautama telah manunggal dengan Sang Hyang Adhi Buddha atau dengan kata lain bahwa Sang Buddha Gautama adalah pengejawantahan dari Sang Adhi Buddha.

Sangha Agung Indonesia menjabarkan Ketuhanan dalam agama Buddha dan mendefisinikan Tuhan sebagai "Sumber dari segala sesuatu yang ada". Dengan sendirinya : Maha Esa, kekal, segala sesuatu dialam semesta adalah babaran dariNya, tidak berwujud dan tidak mewujudkan diriNya, namun segala kata-kata yang indah ini tidak mampu untuk melukiskan keadaan dari Sang Hyang Adi Buddha.

\section{e. Konghucu}

Menurut agama Konghucu Tuhan Yang Maha Esa biasa disebut dengan Huang Tian Shang Di.

Thian (Tian) secara harfiah berarti "langit" yang menunjukkan tempat kediaman dari Shang Di (Siang Te). Sedangkan Shang Di sendiri berarti "Yang Termulia yang berada Paling Atas."

Orang Tianghoa sudah mempercayai adanya "Sesuatu" sebagai penguasa segala sesuatu di jagat raya ini. Sesuatu ini umumnya disebut Shang Di atau Tian, sebab menurut mereka, sesuatu penguasa kedudukannya pastilah di atas.

Sejalan dengan pemujaan Shang Di atau Tian, mereka juga mempercayai bahwa di tempat-tempat tertentu memiliki penguasa-penguasa sendiri (semacam penguasa lokal), sehingga timbul juga pemujaan kepada "penguasa-penguasa lokal" tersebut, (misalnya penguasa sungai, penguasa gunung, penguasa bumi dan sebagainya).

Pemimpin tertinggi dan berkuasa penuh atas jagat raya, dipegang oleh Shang Di dan menteri-menterinya dijabat oleh para dewa, baik sipil maupun militer. Kaisar yang memerintah di daratan Tiongkok dipercaya sebagai utusan dari langit (Shang Di) yang diberi mandate untuk memerintah di bumi. Bagi rakyat, memuja kaisar sebagai itusan Shang Di yang ada di dunia, sudah merupakan wujud pemujaan kepada Shang Di sendiri. 
Dalam ajaran Konfusius dikenalkan adanya tiga unsur dalam alam semesta, yaitu unsur Tiang Huang (penguasa langit). Di Huang (Penguasa Bumi) dan Ren Huang (Penguasa Manusia). Penguasa tertinggi terletak pada Tian Huang atau Tuhan Yang Maha Esa yang disebut sebagai Huang Tian Shang Di.

Dengan masuknya pengaruh Buddhisme, kemudian muncul suatu aliran yang disebut Thian Tao (tian Dao), yang merangkum ketiga ajaran yaitu Taoisme, Konfusianisme, dan Buddhisme. Aliran ini mempertegas nama dan kedudukan Shang Di. Di Indonesia dikenal dengan istilah Tri Dharma.

Menurut mereka, alam semesta ini terdiri dari tiga tingkat, yaitui hi Tiang (Nirwaba), Qi Tian (Kahyangan), dan Xiang Tian (Bumi), Tuhan Yang Maha Esa disebut sebagai Bing Bing Sian Te (Ming Ming Shang Di) dan berkedudukan di hi Tian / Nirwana. Tuhan Yang Maha Esa mengeluarkan firmanNya yang disebut Tao, yang merupakan sumber kebenaran dan sumber kehidupan semua makhluk. Sebagai pelaksana pemerintahan alam semesta di jabat oleh Yu Huang Shang Di, dengan dibantu para dewa-dewi dan malaikat sebagai menteri-menterinya yang berkedudukan di Osi Tian / Kahyangan. Sedangkan sebagai pelaksana pemerintahan di bumi, dijabat oleh pra Huang Di (Kaisar atau Raja).

\section{Kerukunan Umat Beragama}

Secara etimologis kata kerukunan pada mulanya adalah bahasa Arab, yaitu “ "rukun" yang berarti tiang, dasar, sila. Jamak rukun adalah "arkaan"; artinya suatu bangunan sederhana yang terdiri dari berbagai unsur. Dari kata arkaan diperoleh pengertian, bahwa kerukunan merupakan suatu kesatuan yang terdiri dari berbagai unsur yang berlainan dan setiap unsur tersebut saling menguatkan. Kesatuan tidak dapat terwujud jika ada diantara unsur tersebut yang tidak berfungsi (Khalid, 1988:658).

Dalam pengertian sehari-hari kata rukun dan kerukunan identik dengan damai dan kedamaian. Dengan pengertian ini jelas, bahwa kata kerukunan hanya dipergunakan dan berlaku dalam dunia pergaulan. Dengan demikian kerukunan antar umat beragama bukan berarti merelatifir agama-agama yang ada dengan melebur kepada satu totalitas (sinkretisme agama) dengan menjadikan agamaagama yang ada itu sebagai mazhab dari agama totalitas tersebut, melainkan sebagai cara atau sarana untuk mempertemukan, mengatur hubungan luar antara orang yang tidak seagama atau antara golongan umat beragama dalam setiap proses kehidupan sosial kemasyarakatan.

Dengan kerukunan dimaksudkan agar terbina dan terpelihara hubungan baik dalam pergaulan antara warga yang berlainan agama, urgensi kerukunan adalah 
untuk mewujudkan kesatuan pandangan yang membutuhkan kesatuan sikap, guna melahirkan kesatuan perbuatan dan tindakan. Sedangkan kesatuan perbuatan dan tindakan menanamkan rasa tanggung jawab bersama umat beragama, sehingga tidak ada pihak yang melepaskan diri dari tanggung jawab atau menyalahkan pihak lain. Dengan kerukunan umat beragama, masyarakat menyadari bahwa negara adalah milik bersama dan menjadi tanggung jawab bersama umat beragama. Karena itu, kerukunan antar umat beragama bukanlah kerukunan sementara, bukan pula kerukunan politis, tapi kerukunan hakiki yang dilandasi dan dijiwai oleh agama masing-masing.

Secara historis, kerukunan dalam pergaulan hidup telah menjadi milik dan ciri bangsa Indonesia sendiri sejak zaman leluhur dahulu. Maka mewujudkan kerukunan antar umat beragama sebenarnya bukan merupakan usaha baru, tetapi sebagai bagian dari usaha dalam memelihara identitas dan integritas bangsa dan negara.

Sebagai negara berkembang, Indonesia perlu memantapkan identitas yang mengakar secara kultural dalam masyarakat. Dengan kerukunan antar umat beragama Indonesia dapat memantapkan identitas bangsanya tanpa mencontoh identitas bangsa-bangsa lain. Tidak mustahil pada masa-masa yang akan datang bangsa Indonesia memberikan kerukunan antar umat beragama Indonesia dapat memantapkan identitas bangsanya tanpa mencontoh identitas bangsa-bangsa lain. Tidak mustahil pada masa-masa yang akan datang bangsa Indonesia memberikan sumbangan dan berperan dalam menciptakan dan mengisi terwujudnya kerukunan dan kebersamaan antar umat beragama. Tidak mustahil pula bangsabangsa lain akan belajar kepada bangsa Indonesia dalam membina dan memelihara kesatuan dan persatuan bangsa, terutama bangsa yang terdiri dari berbagai golongan umat beragama (Al-Munawar, 2003:5-6).

Antara agama memiliki semangat jika tidak dikatakan memiliki titik temu yang sama, sebagaimana yang telah diinformasikan dalam Al Qur'an : "Katakanlah (Muhammad) Wahai Ahli Kitab! Marilah (kita) menuju kepada satu kalimat (pegangan) yang sama antara kami dan kamu, bahwa kita tidak menyembah selain Allah dan kita tidak mempersekutukan-Nya dengan sesuatu apapun, dan bahwa kita tidak menjadikan satu sama lain Tuhan-Tuhan selain Allah. Jika mereka berpaling maka katakanlah (kepada mereka), "Saksikanlah, bahwa kami adalah orang muslim" (QS. Ali Imran [3] : 64).

Setiap pemeluk agama memiliki kesamaan (kalimat sawa) semangat iman kepada Tuhan, berbuat baik, kepedulian kepada kaum lemah, ketidak adilan dan penyelewengan-penyelewengan sosial lainnya. 
Setiap agama mengajarkan jalan hidup yang berbeda-beda dan merupakan ekspresi dari pemeluknya untuk memahami ajaran Tuhan. Karena Bangsa Indonesia hidup dalam suasana masyarakat serba jamak (plural society), maka dibutuhkan jalan untuk mencapai kerukunan dalam kehidupan keagamaan.

Pola agree in disagreement" ini mengajarkan bahwa agama yang ia peluk itulah yang paling baik, dan mempersilakan orang lain untuk mempercayai bahwa agama yang dipeluknya adalah agama yang paling baik. Tipologi ini mengajarkan bahwa setiap agama memiliki perbedaan dan persamaan. Sikap yang perlu dikembangkan dalam kaitan ini adalah saling menghargai antar pemeluk agama. Pola ini adalah yang paling relevan di jalankan oleh setiap pemeluk agama. Dikatakannya, orang yang beragama harus percaya bahwa agama yang ia peluk itulah yang paling baik dan paling benar, dan orang lain juga dipersilahkan bahkan dihargai, untuk mempercayai dan meyakini kebenaran agama yang dianutnya.

Mukti Ali juga menekankan bahwa sikap agre in disagreement harus diwujudkan untuk menghadapi problem keragaman paham keberagaman. Seperti difirmankan Allah SWT dalam Al Qur'an bahwa keragaman itu jika dipahami secara positif justru akan menjadi ujian. Tuhan utama paham-paham keagamaan yang berbeda adalah berlomba-lomba menjadi umat yang terbaik. Karena itu, biarlah sejarah yang akan membuktikan golongan mana yang paling banyak memberikan manfaat dalam kehidupan umat (Wahid, 2015:272-273).

Untuk menguatkan kerukunan umat beragama di Indonesia yang ber Bhinneka Tunggal Ika ini, maka secara yuridis Pemerintah Republik Indonesia telah mengeluarkan Peraturan Bersama Menteri Agama dan Menteri Dalam Negeri Nomor : 8 dan 9 Tahun 2006 tentang Pedoman Pelaksanaan Tugas Kepala Daerah / Wakil Kepala Daerah dalam Pemeliharaan Kerukunan Umat Beragama, Pemberdayaan Forum Kerukunan Umat Beragama, dan Pendirian Rumah Ibadat.

Dalam Peraturan Bersama Menteri Agama dan Menteri Dalam Negeri tersebut, antara lain dijelaskan :

a. Kerukunan umat beragama adalah keadaan hubungan sesama umat beragama yang dilandasi toleransi, saling pengertian, saling menghormati, menghargai kesetaraan dalam pengamalan ajaran agamanya dan kerjasama dalam kehidupan bermasyarakat, berbangsa dan bernegara di dalam Negara Kesatuan Republik Indonesia berdasarkan Pancasila dan Undang-Undang Dasar Negara Republik Indonesia Tahun 1945.

b. Pemeliharaan kerukunan umat beragama adalah upaya bersama untuk beragama dan pemerintah di bidang pelayanan pengaturan, dan pemberdayaan umat beragama.

JAS: Volume 1 Nomor 2, 2019 
c. Bahwa hak beragama adalah hak asasi manusia yang tidak dapat dikuragi dalam keadaan apapun.

\section{A. Simpulan}

Kebinekaan beragama dalam perspektif Hukum Islam adalah merupakan Sunnatullah (hukum kodrat), sebagaimana firman Allah SWT : "sekiranya Allah menghendaki, niscaya kamu dijadikanNya satu umat saja, tetapi Allah hendak menguji kamu terhadap pemberianNya kepadamu, maka berlomba-lombalah berbuat kebajikan". (QS. Al Maidah : 48).

Nilai-nilai kebinekaan merupakan warisan tradisi Nusantara yang menjadi pemersatu bangsa ini. Oleh karena itu menjaga kebinekaan, khususnya dalam beragama di Indonesia adalah suatu keniscayaan.

Kesadaran umat dan bangsa akan kebinekaan beragama serta menghargai nilai-nilai kemanusiaan dan kemerdekaan baik yang tercantum dalam Undang-Undang Dasar 1945 maupun yang terdapat dalam tradisi dan budaya bangsa Indonesia, akan menciptakan sikap toleransi dan kerukunan umat beragama di Indonesia semakin kokoh.

\section{Daftar Rujukan}

Akhamd Sahal dan Munawir Aziz (Ed), (2015), Islam Nusantara, dari Uskul Fiqh Hingga Paham Kebangsaan, PT. Mizan Pustaka, Bandung.

Loudy Fatoohi, (2013), The mystery of Historical Jesus, Sang Mesias menurut Al Qur'an, Alkitab, dan Sumber-Sumber Sejarah, PT. Mizam Pustaka, Bandung.

Pusat Kerukunan Umat Beragama Kementerian Agama Republik Indonesia, (2014), Kitab Suci Agama Khonghucu Si Shu, PT. Sumber Agung Mitra Sejati, Jakarta.

Said Agil Husin Al Munawar, Prof, Dr. H. MA., (2003), Fikih Hubungan Antar Agama, Ciputat Press, Jakarta.

T.D. Singh, Ph.D, (2009) Seri Vedanta \& Sains, Realitas Keberadaan Tuhan, PT. Temprina Media Grafika, Bali.

Wawan Gunawan Abd. Wahid, dkk. (Ed) (2015), Fikih Kebinekaan Pandangan Islam Indonesia Tentang Umat, Kewargaan dan Kepemimpinan Non Muslim, PT. Mizan Pustaka, Bandung. 